\title{
Successful sofosbuvir treatment with ribavirin dose reduction for chronic hepatitis $C$ virus genotype 2 infection in a patient with ulcerative colitis: a case report
}

\author{
Yuki Ohta ${ }^{1}$, Tatsuo Kanda ${ }^{1 *}$, Tatsuro Katsuno ${ }^{1}$, Shin Yasui ${ }^{1}$, Yuki Haga ${ }^{1}$, Reina Sasaki ${ }^{1}$, Masato Nakamura',
} Shuang $\mathrm{Wu}^{1}$, Shingo Nakamoto ${ }^{2}$, Makoto Arai $^{1}$ and Osamu Yokosuka ${ }^{1}$

\begin{abstract}
Background: Ulcerative colitis is a lifelong, immunologically mediated disease. Direct-acting antivirals (DAAs) are now available for the treatment of chronic hepatitis $\mathrm{C}$ virus ( $\mathrm{HCV}$ ) infection. An interferon-free regimen appears useful, safe and effective for many patients for whom interferon-based treatment is contraindicated.

Case presentation: We studied a 56-year-old treatment-naïve Japanese man with chronic HCV genotype 2b infection who had ulcerative colitis. This patient was treated with sofosbuvir and ribavirin for 12 weeks. During treatment, diarrhoea and bloody faeces were frequent. After ribavirin was reduced to $400 \mathrm{mg}$ daily, these symptoms decreased. Finally, the patient achieved a sustained virologic response 12 weeks after the stoppage of the treatment.

Conclusion: Clinicians should pay careful attention to the ribavirin dose in the treatment of certain HCV patients with inflammatory bowel disease who are receiving sofosbuvir plus ribavirin.
\end{abstract}

Keywords: Case report, Direct-acting antiviral (DAA), Hepatitis C virus (HCV), Interferon-free, Ribavirin, Ulcerative colitis

\section{Background}

Inflammatory bowel disease (IBD), which comprises ulcerative colitis and Crohn's disease, is a chronic immunologically mediated disease [1]. There are highprevalence populations of IBD in North America and Europe [1]. In India and Japan, the incidence is increasing [1]. Ulcerative colitis is a lifelong, immunologically mediated disease and results from the inappropriate activation of the mucosal immune system by intestinal luminal antigens [2], although the progress in treatment of ulcerative colitis has been observed [2,3].

The prevalences of hepatitis B virus (HBV) and hepatitis $\mathrm{C}$ virus (HCV) in patients with IBD are similar to those in the general population $[4,5]$, although these data are controversial [6,7]. Because the prevalences of $\mathrm{HBV}$ and $\mathrm{HCV}$ are higher in Asian countries, including

\footnotetext{
* Correspondence: kandat-cib@umin.ac.jp

${ }^{1}$ Department of Gastroenterology and Nephrology, Chiba University,

Graduate School of Medicine, 1-8-1 Inohana, Chuo-ku, Chiba 260-8670, Japan Full list of author information is available at the end of the article
}

Japan, than those in non-Asian countries [8, 9], the management of these infectious diseases is still important in patients with IBD.

Interferon- $\alpha$, which was previously the most common treatment for $\mathrm{HCV}$, is a proinflammatory cytokine and can provoke a relapse of ulcerative colitis [10]. The synthetic guanosine analogue ribavirin (1-beta-D-ribofuranosyl-1,2,4-triazole-3-carboxamide) is also used for HCV eradication [11, 12]. The exacerbation of ulcerative colitis has also been reported during and/or after combination therapy with peginterferon plus ribavirin for chronic hepatitis C [13-15].

Recent advances in the treatment of patients infected with $\mathrm{HCV}$ make it possible to eradicate this virus with interferon-free regimens. Sofosbuvir is a potent nucleotide inhibitor for HCV RNA-dependent polymerase [16]. The combination of sofosbuvir and ribavirin led to higher sustained virologic response (SVR) rates in $\mathrm{HCV}$ genotype 2-infected individuals [16]. We report an ulcerative colitis-patient who was chronically infected 
with $\mathrm{HCV}$ genotype 2 and was successfully treated with sofosbuvir plus dose reduction of ribavirin for 12 weeks.

\section{Case presentation}

A 56-year-old man with a 31-year history of ulcerative colitis was diagnosed with $\mathrm{HCV}$ infection at age 46 . The patient received a blood transfusion at age 4 when he had surgery for his jaw and denied other risk factors for $\mathrm{HCV}$ infection, including tattoos or intravenous drug use. The patient drank alcohol ( 21 g daily) for 20 years; had a medical history of hypertension, IgA nephropathy, type 2 diabetes mellitus and dilated cardiomyopathy; and took several medications for these diseases. His ulcerative colitis was relatively well-controlled with oral sarazopyridine (4500 mg daily) and a sarazopyridine suppository (300 mg daily). The HCV genotype was $2 b$, and the patient was interferon treatment-naïve because he had ulcerative colitis, an autoimmune disease.

The patient's height and body weight were $172 \mathrm{~cm}$ and $88.3 \mathrm{~kg}$, respectively, and his body temperature was $35.2{ }^{\circ} \mathrm{C}$. His laboratory findings before treatment are shown in Table 1. Abdominal ultrasound findings showed no masses in the liver and no ascites. Liver stiffness as measured by transient elastography was $7.6 \mathrm{kPa}$, indicating the absence of cirrhosis. Although he had chronic significant amount of alcohol intake, the ultrasound findings did not show the fatty change of the liver. He wanted to be treated for his chronic hepatitis $\mathrm{C}$.

The patient was treated with sofosbuvir at $400 \mathrm{mg}$ daily and ribavirin at $600 \mathrm{mg}$ daily. One week after the initiation of this treatment, the patient felt general malaise without any adverse events [white blood cell count (WBC), 7900/ $\mathrm{L}$; hemoglobin, $14.7 \mathrm{~g} / \mathrm{dL} ; \mathrm{C}$-reactive protein (CRP) $0.0 \mathrm{mg} / \mathrm{dL}$; AST, $35 \mathrm{IU} / \mathrm{L}$; and ALT, $49 \mathrm{IU} / \mathrm{L}]$. By week 3 , the patient was having up to 10 loose bowel movements per day, with small amounts of blood. As the patient's HCV RNA became negative and he improved to having 5 loose bowel movements per day by week 4 [WBC, $8600 / \mu \mathrm{L}$; hemoglobin, $14.3 \mathrm{~g} / \mathrm{dL}$; AST, $19 \mathrm{IU} / \mathrm{L}$; and ALT, $19 \mathrm{IU} / \mathrm{L}]$, the dose of ribavirin was increased to $800 \mathrm{mg}$ daily. By week 7 , however, the patient was having up to 20 loose bowel movements per day, with small amounts of blood, and the dose of ribavirin was decreased to $400 \mathrm{mg}$ daily [WBC, $8200 / \mu \mathrm{L}$; hemoglobin, $14.7 \mathrm{~g} / \mathrm{dL}$; CRP $0.1 \mathrm{mg} / \mathrm{dL}$; AST, $19 \mathrm{IU} / \mathrm{L}$; and ALT, $17 \mathrm{IU} / \mathrm{L}]$. By week 8, the patient improved to having 10 loose bowel movements per day [WBC, $8600 / \mu \mathrm{L}$; hemoglobin, $14.2 \mathrm{~g} / \mathrm{dL}$; CRP $0.1 \mathrm{mg} / \mathrm{dL}$; AST, $20 \mathrm{IU} / \mathrm{L}$; and ALT, $17 \mathrm{IU} / \mathrm{L}]$, and by week 11, his diarrhoea had resolved. Finally, the patient was treated with sofosbuvir plus ribavirin for 12 weeks. By week 12 after the initiation of this treatment, the patient's HCV RNA was negative, and he had achieved a SVR 12 weeks (SVR12) after the stoppage of treatment [WBC, 14400/ $\mu \mathrm{L}$; hemoglobin, $16.2 \mathrm{~g} / \mathrm{dL}$; CRP $0.2 \mathrm{mg} / \mathrm{dL}$; AST, $22 \mathrm{IU} / \mathrm{L}$; and ALT, $22 \mathrm{IU} / \mathrm{L}$ ] (Fig. 1). Three weeks post-treatment, an endoscopic examination of the colon-rectum confirmed that the mucosa was oedematous from the colon transversum to the rectum, although mucosal vascular permeability was reduced from the sigmoid colon to the rectum. The patient did not complain of abdominal pain or fever during treatment.

\section{Discussion}

In the present report, we present a 56-year-old HCV genotype 2-infected patient who was diagnosed with ulcerative colitis and achieved a SVR12 after combination

Table 1 Laboratory findings before treatment

\begin{tabular}{|c|c|c|c|c|c|}
\hline Item & Value & Item & Value & Item & Value \\
\hline AST & $51 \mathrm{IU} / \mathrm{L}$ & BUN & 16 mg/dL & $\mathrm{HBsAg}$ & negative \\
\hline ALT & $66 \mathrm{IU} / \mathrm{L}$ & Creatinine & $0.68 \mathrm{mg} / \mathrm{dL}$ & Anti-HCV & positive \\
\hline LDH & $256 \mathrm{IU} / \mathrm{L}$ & UA & $4.3 \mathrm{mg} / \mathrm{dL}$ & HCV RNA & $6.4 \mathrm{log} \mid \mathrm{U} / \mathrm{mL}$ \\
\hline ALP & $96 \mathrm{IU} / \mathrm{L}$ & $\mathrm{Na}$ & 136 mEq/L & HCV genotype & $2 b$ \\
\hline$\gamma$-GTP & $88 \mathrm{IU} / \mathrm{L}$ & K & $3.9 \mathrm{mEq} / \mathrm{L}$ & Anti-HIV & negative \\
\hline T. Bil & $1.2 \mathrm{mg} / \mathrm{dL}$ & $\mathrm{Cl}$ & 104 mEq/L & Hyaluronic acid & 37 ng/mL \\
\hline TP & $7.1 \mathrm{~g} / \mathrm{dL}$ & WBC & $5900 / \mu \mathrm{L}$ & AFP & $7.4 \mathrm{ng} / \mathrm{mL}$ \\
\hline Albumin & $3.9 \mathrm{~g} / \mathrm{dL}$ & $\mathrm{RBC}$ & $477 \times 10^{4} / \mu \mathrm{L}$ & PIVKA-II & $32 \mathrm{mAU} / \mathrm{mL}$ \\
\hline Amylase & $83 \mathrm{IU} / \mathrm{L}$ & Hemoglobin & $14.4 \mathrm{~g} / \mathrm{dL}$ & $\mathrm{NH}_{3}$ & $58 \mu \mathrm{g} / \mathrm{dL}$ \\
\hline CPK & $102 \mathrm{IU} / \mathrm{L}$ & Haematocrit & $40.7 \%$ & $\mathrm{HbA1c}$ & $7.8 \%$ \\
\hline T.CHO & 115 mg/dL & Platelets & $15.6 \times 10^{4} / \mu \mathrm{L}$ & CRP & $0.1 \mathrm{mg} / \mathrm{dL}$ \\
\hline TG & 103 mg/dL & PT & $100 \%$ & & \\
\hline
\end{tabular}

AFP a-Fetoprotein, ALP alkaline phosphatase, BUN blood urea nitrogen, $C P K$ creatine phosphokinase, CRP C-reactive protein, $H b A 1 c$ haemoglobin A1c, $L D H$ lactate dehydrogenase, PIVKA-II protein induced by vitamin K absence or antagonists-Il, PT prothrombin time, RBC red blood cell count, T.Bil total bilirubin, T.CHO total cholesterol, TG triglyceride, TP total protein, UA uric acid, WBC white blood cell count 


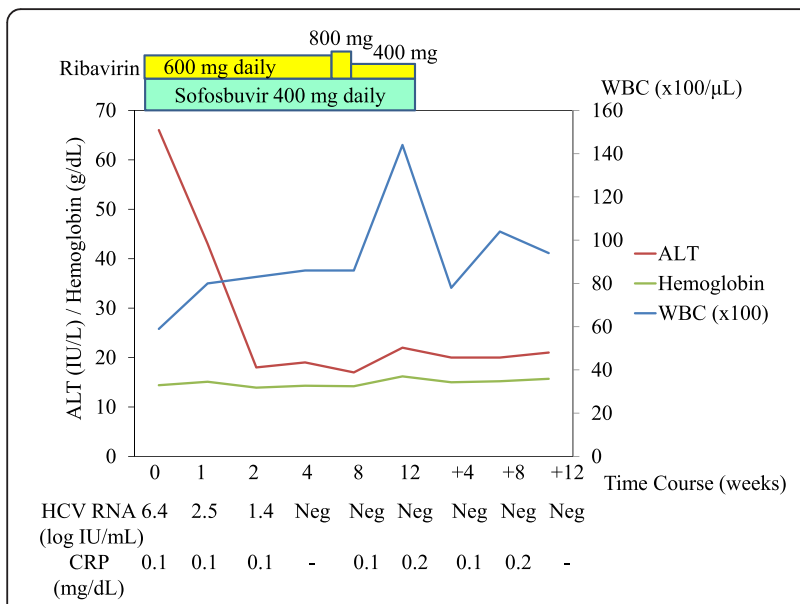

Fig. 1 Clinical course of the patient. ALT alanine transaminase, WBC white blood cells, $w$ weeks, Neg negative

treatment with sofosbuvir plus ribavirin for 12 weeks. In Japanese multicentre, open-label phase 3 trial, $\mathrm{HCV}$ genotype 2-infected patients received 12 weeks of treatment with $400 \mathrm{mg}$ of sofosbuvir, administered orally once daily, and ribavirin, administered orally twice daily, with doses determined according to body weight (1000 mg daily in patients with a body weight of $>80 \mathrm{~kg}$ ) [17]. But initial dose of the present case was $600 \mathrm{mg}$ daily because we are afraid of adverse events of ribavirin. During treatment, the patient's diarrhoea worsened, and the reduction of ribavirin with no reduction of sofosbuvir led to improvement in this symptom and the completion of therapy.

The mechanism of the inhibition of $\mathrm{HCV}$ replication by ribavirin is as follows: (1) ribavirin induces mutagenesis in HCV RNA; (2) ribavirin inhibits HCV RNAdependent polymerase; (3) ribavirin inhibits the inosine monophosphate dehydrogenase enzyme and reduces intracellular guanosine pools, which are essential for $\mathrm{HCV}$ replication; and (4) ribavirin stimulates the T helper 1 (Th1) antiviral response, which leads to $\mathrm{HCV}$ eradication $[8,11,12]$. Ulcerative colitis is vaguely associated with abnormal Th2 immunity [18]. Although we do not know the exact effects of ribavirin on mucosal immunity, ribavirin worsened the symptoms of the present case with ulcerative colitis.

Although 12-week-treatment with sofosbuvir and ribavirin could lead to diarrhoea in $9 \%$ of HCV genotype 2/ 3-infected patients [16], of interest, 12-week-treatment with sofosbuvir and ledipasvir could lead to diarrhoea in only $4 \%$ of HCV genotype 1 -infected patients [19]. We could not completely rule out the possibility that the combination of sofosbuvir plus ribavirin might be responsible, compared the only ribavirin.

One year before treatment, an endoscopic examination of the colon-rectum demonstrated that mucosal vascular permeability was reduced from the sigmoid colon to the rectum with marked mucus exudates. We could not completely rule out the possibility that this patient had baseline active mucosal disease but asymptomatic and then developed diarrhoea due to the sofosbuvir and ribavirin treatment. Although one important differential diagnosis of flare of ulcerative colitis is infection, as this patient did not have a high fever, we did not perform stool culture or use any antibiotics other than sarazopyridine. So we excluded bacterial infection in this patient.

$\mathrm{HCV}$ infection is a current leading cause of HCC in Japan and the United States [12]. This patient should be followed up for the occurrence of HCC [12]. Coexistence of IBD and chronic liver diseases, including chronic hepatitis $C$, leads to higher mortality rates than IBD alone [20]. Interferon-free therapy with or without ribavirin could increase treatment efficacy and shorten treatment duration compared with previous standards of care, such as peginterferon plus ribavirin treatment. However, the clinician should pay special attention to the use of ribavirin in the management of $\mathrm{HCV}$-infected patients with IBD.

\section{Conclusion}

We studied a HCV genotype 2b-infected patient with an ulcerative colitis exacerbation during sofosbuvir plus ribavirin treatment. The reduction of ribavirin improved this symptom, and the patient finally achieved a SVR12. Clinicians should pay careful attention to the ribavirin dose in the treatment of certain HCV patients with inflammatory bowel diseases, such as ulcerative colitis, in sofosbuvir plus ribavirin treatment.

\section{Abbreviations}

HBV, hepatitis B virus; HCV, hepatitis C virus; IBD, inflammatory bowel disease; SVR, sustained virologic response; SVR12, SVR at 12 weeks; Th, T helper

Acknowledgements

Authors thank all Chiba University Hospital's staff for patient's care.

Funding

Not applicable.

Availability of data and materials

Not applicable.

Authors' contributions

YO, TK and TK saw the patient and drafted the manuscript. All authors revised manuscript and approved the final manuscript.

\section{Competing interests}

TK and OY received lecture fees from Gilead Sciences. The other authors have no competing interest to disclose.

\section{Consent for publication}

Written informed consent was obtained from the patient for the publication of this case report and these data. A copy of the written consent is available for review by the editor of this journal. This case report did not require the review by the Institutional Review Board of Chiba University School of Medicine. 


\section{Ethics approval and consent to participate}

Not applicable.

\section{Author details}

'Department of Gastroenterology and Nephrology, Chiba University, Graduate School of Medicine, 1-8-1 Inohana, Chuo-ku, Chiba 260-8670, Japan. 'Department of Molecular Virology, Chiba University, Graduate School of Medicine, 1-8-1 Inohana, Chuo-ku, Chiba 260-8670, Japan.

Received: 17 February 2016 Accepted: 7 June 2016

Published online: 11 July 2016

\section{References}

1. Ananthakrishnan AN. Epidemiology and risk factors for IBD. Nat Rev Gastroenterol Hepatol. 2015;12(4):205-17.

2. Lawrance IC. Early investigational TNF receptor antagonists for the treatment of ulcerative colitis. Expert Opin Investig Drugs. 2015;24(6):761-8.

3. Seo GS, Chae SC. Biological therapy for ulcerative colitis: an update. World I Gastroenterol. 2014;20(37):13234-8.

4. Papa A, Felice C, Marzo M, Andrisani G, Armuzzi A, Covino M, et al. Prevalence and natural history of hepatitis $B$ and $C$ infections in a large population of IBD patients treated with anti-tumor necrosis factor-a agents. J Crohns Colitis. 2013;7(2):113-9.

5. Chevaux JB, Nani A, Oussalah A, Venard V, Bensenane M, Belle A, et al. Prevalence of hepatitis $B$ and $C$ and risk factors for nonvaccination in inflammatory bowel disease patients in Northeast France. Inflamm Bowel Dis. 2010;16(6):916-24

6. Loras C, Saro C, Gonzalez-Huix F, Mínguez M, Merino O, Gisbert JP, et al. Prevalence and factors related to hepatitis B and $\mathrm{C}$ in inflammatory bowel disease patients in Spain: a nationwide, multicenter study. Am J Gastroenterol. 2009;104(1):57-63.

7. Lidar M, Langevitz P, Barzilai O, Ram M, Porat-Katz BS, Bizzaro N, et al. Infectious serologies and autoantibodies in inflammatory bowel disease: insinuations at a true pathogenic role. Ann N Y Acad Sci. 2009;1173:640-8.

8. Omata M, Kanda T, Yu ML, Yokosuka O, Lim SG, Jafri W, et al. APASL consensus statements and management algorithms for hepatitis $C$ virus infection. Hepatol Int. 2012:6(2):409-35.

9. Sarin SK, Kumar M, Lau GK, Abbas Z, Chan HL, Chen CJ, et al. Asian-Pacific clinical practice guidelines on the management of hepatitis B: a 2015 update. Hepatol Int. 2016;10(1):1-98.

10. Sawada K, Ohnishi K, Fukunaga K, Shimoyama T. A new treatment for HCVulcerative colitis comorbidity intolerant to INF-alpha. Am J Gastroenterol. 2003;98(1):228-9.

11. Kanda T, Yokosuka O, Imazeki F, Tanaka M, Shino Y, Shimada H, et al. Inhibition of subgenomic hepatitis C virus RNA in Huh-7 cells: ribavirin induces mutagenesis in HCV RNA. J Viral Hepat. 2004;11(6):479-87.

12. Kanda T, Imazeki F, Yokosuka O. New antiviral therapies for chronic hepatitis C. Hepatol Int. 2010:4(3):548-61.

13. Sprenger R, Sagmeister M, Offner F. Acute ulcerative colitis during successful interferon/ribavirin treatment for chronic hepatitis. Gut. 2005:54(3):438-9.

14. Tursi A. Rapid onset of ulcerative colitis after treatment with PEG-interferon plus ribavirin for chronic hepatitis C. Inflamm Bowel Dis. 2007;13(9):1189-90.

15. Morimoto K, Yamagami H, Hosomi S, Ohira M, Suekane T, Kamata N, et al. Development of pouchitis with combination therapy with peg-interferon alpha-2b and ribavirin for chronic hepatitis $\mathrm{C}$ in a patient with ulcerative colitis who underwent pouch surgery. Am J Gastroenterol. 2009;104(6):1609-10.

16. Jacobson IM, Gordon SC, Kowdley KV, Yoshida EM, Rodriquez-Torres M, Sulkowski MS, et al. Sofosbuvir for hepatitis C genotype 2 or 3 in patients without treatment options. N Engl J Med. 2013:368(20):1867-77.

17. Omata M, Nishiguchi S, Ueno Y, Mochizuki H, Izumi N, Ikeda F, et al. Sofosbuvir plus ribavirin in Japanese patients with chronic genotype $2 \mathrm{HCV}$ infection: an open-label, phase 3 trial. J Viral Hepat. 2014;21(11):762-8.

18. Neurath MF, Finotto $S$, Glimcher LH. The role of Th1/Th2 polarization in mucosal immunity. Nat Med. 2002;8(6):567-73.

19. Kowdley KV, Gordon SC, Reddy KR, Rossaro L, Bernstein DE, Lawitz E, et al. Ledipasvir and sofosbuvir for 8 or 12 weeks for chronic HCV without cirrhosis. N Engl J Med. 2014;370:1879-88.

20. Bargiggia S, Thorburn D, Anderloni A, Ardizzone S, Giorgi A, Bianchi Porro G, et al. Is interferon-alpha therapy safe and effective for patients with chronic hepatitis $\mathrm{C}$ and inflammatory bowel disease? A case-control study. Aliment Pharmacol Ther. 2005;22(3):209-15.

\section{Submit your next manuscript to BioMed Central and we will help you at every step:}

- We accept pre-submission inquiries

- Our selector tool helps you to find the most relevant journal

- We provide round the clock customer support

- Convenient online submission

- Thorough peer review

- Inclusion in PubMed and all major indexing services

- Maximum visibility for your research

Submit your manuscript at www.biomedcentral.com/submit
Biomed Central 